\title{
Aspects of fiscal/debt management and monetary policy interaction: the recent experience of Saudi Arabia
}

\author{
Abdulrahman Al-Hamidy ${ }^{1}$
}

\begin{abstract}
As Saudi Arabia's oil export revenues constitute about $90 \%$ of its budget, its fiscal policy is largely a function of developments in the oil market. Over the years, a countercyclical fiscal stance has been used to reduce the volatility of domestic growth against the background of vacillating oil revenues. Given the structure of the economy, the need is to continue to encourage the private sector to assume a greater role in the country's diversification efforts. Reflecting the dominance of fiscal policy in Saudi Arabia and its impact on economic growth, the primary aim of monetary policy is to assure exchange rate stability with a view to providing an environment that is conducive to financial stability and sustainable growth. The interaction between monetary and fiscal policy has changed in the current global economic and financial climate. Greater cooperation between the fiscal and monetary authorities has become indispensable in meeting macroeconomic objectives. It is envisaged that policy interaction can return to normal modes of operation as the global economic recovery takes hold.
\end{abstract}

Keywords: Saudi Arabia; experiences; fiscal; monetary; policy interactions; countercyclical; exchange rate; stability.

JEL classification: E32, E44, E52, E63, F31

1 Vice Governor, Saudi Arabian Monetary Agency. 


\section{Introduction}

The current euro zone sovereign debt crisis and worsening debt dynamics in major industrial economies reflect elevated risks in sovereign overindebtedness with adverse consequences for economic growth in affected countries. In an age of fiscal austerity and overstretched monetary policy accommodation, the conventional interaction appears to be losing its effectiveness in reviving the economy.

\section{Saudi Arabia's experience}

\section{(i) Relevance of export revenues in the oil sector}

As Saudi Arabia is a resource-based economy, with oil export revenues constituting about $90 \%$ of its budget, its fiscal policy is largely a function of developments in the oil market. Over the years, a countercyclical fiscal stance has been used to reduce the volatility of domestic growth against the background of vacillating oil revenues. With the improvement in the oil market since 2003, fiscal spending has risen and there have been enlarged fiscal surpluses. In fact, part of these cumulative budget surpluses has been used to redeem government debt, which stood at about $10 \%$ of GDP by the end of 2010 , down from its peak of over $100 \%$ in 1999. As is the case in most emerging market economies, fiscal policy remains dominant in stimulating private sector growth.

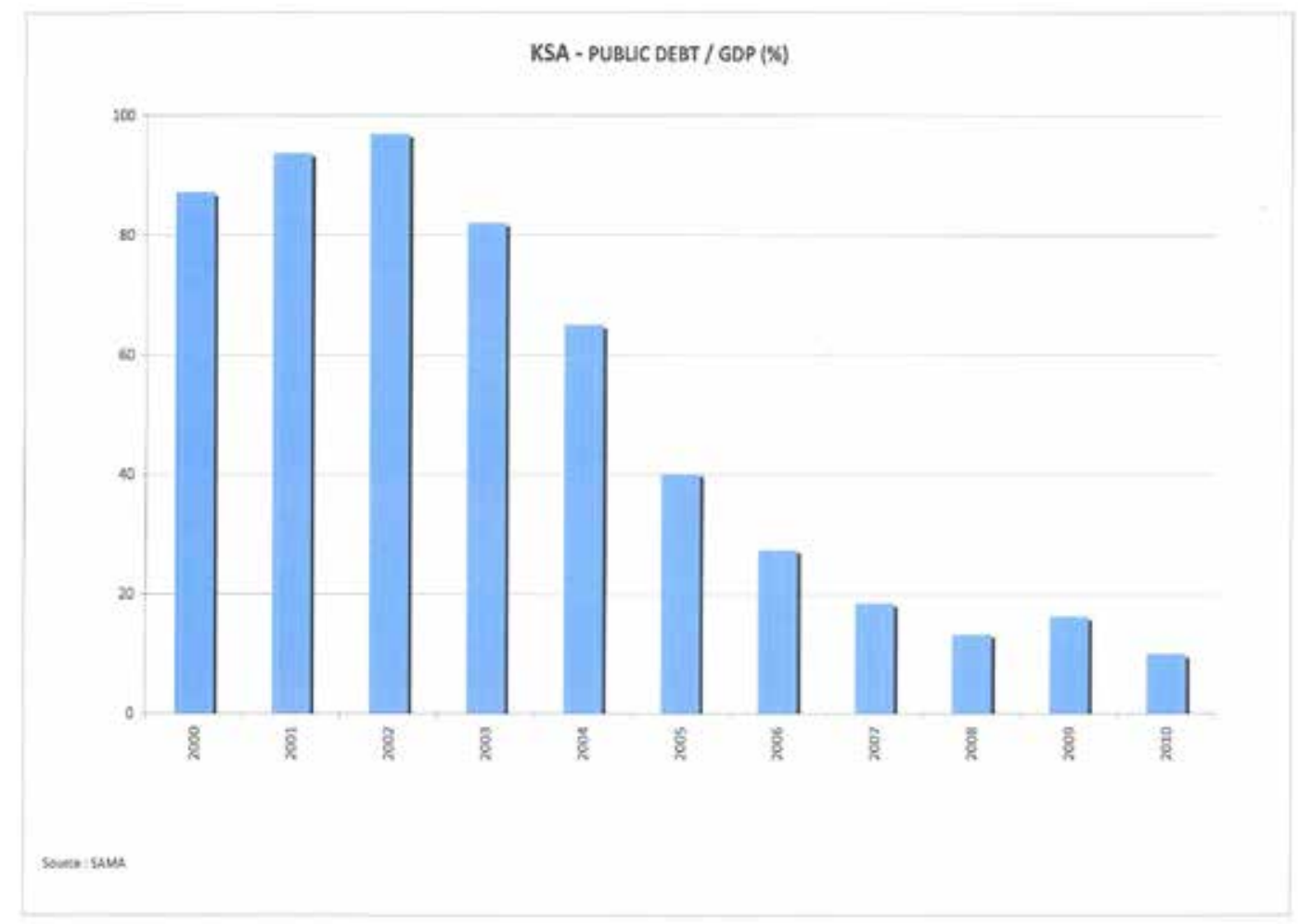

\section{(ii) Policy challenges for the Saudi government}

In Saudi Arabia, all oil revenues accrue to the government. While higher oil revenues are beneficial, they also entail many challenges. The three major and competing considerations are: (a) cyclical, ie containing inflation, which calls for fiscal restraint; (b) secular, ie ensuring 
that oil revenues are distributed through investments in value-added sectors with a focus on projects that are job-creating and socially valuable; and (c) the preservation of intergenerational equity with the twin plans of accumulating foreign assets and increasing economic diversification by investing in physical and social infrastructure. The government budget prioritises spending in health, education and infrastructure. Putting a high weight on ensuring intergenerational equity and long-term fiscal sustainability is consistent with shortrun cyclical considerations when inflationary pressure is high (ie consistent with fiscal restraint). Creating a favourable environment for long-term economic diversification via public investment is consistent with a more expansionary fiscal policy. During the past decade, the diversification motive has been particularly strong in Saudi Arabia, as reflected in massive investment programmes.

\section{(iii) Monetary policy}

Saudi Arabia's monetary regime is effectively its exchange rate regime. SAMA's monetary policy objectives are to maintain the dollar/riyal exchange rate within the framework of the pegged exchange rate regime with a view to pursuing price stability and safeguarding financial stability.

In a fixed exchange rate regime, interest rate policy is largely influenced by monetary developments in the anchor currency country. Notwithstanding this limitation, there are other policy options, such as the application of reserve requirements and prudential guidelines on bank credit to steer monetary policy in the desired direction.

Higher interest rates and exchange rate appreciation have limited impact on curbing inflation that is driven by supply shocks such as higher food prices, as consumption of such goods tends not to be credit-financed. Since demand for food is price-inelastic, higher interest rates can constrain overall demand but will have little effect on food prices. In the recent past, Saudi Arabia's inflation has been largely driven by supply shocks, which cannot be successfully addressed by higher interest rates. Indeed, rate hikes are more likely to soften growth than dampen prices. But inflation has moderated recently in line with falling food prices and softening rent charges.

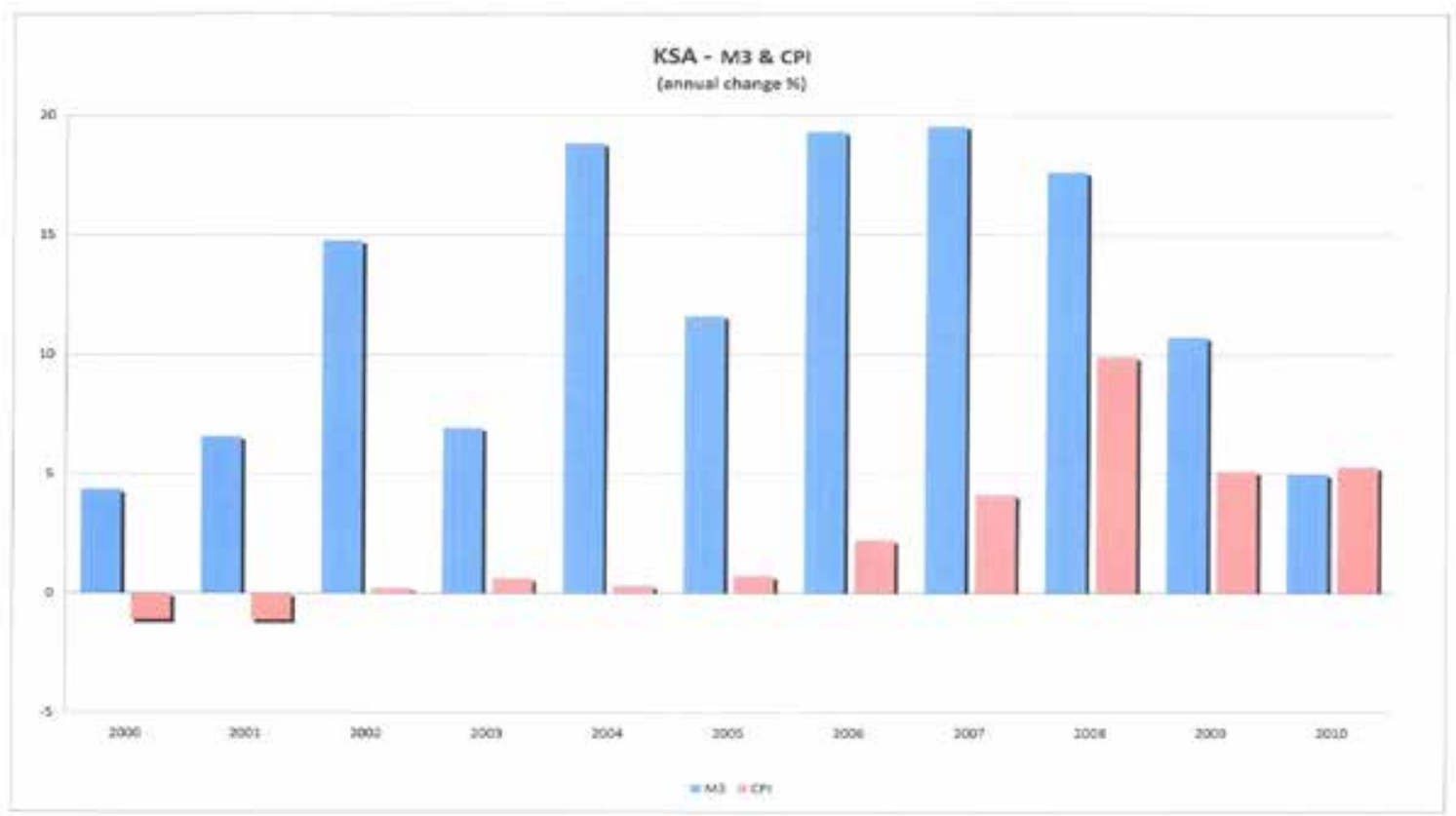




\section{(iv) The monetary process and causative factors for the money supply}

The monetary process in an oil-based economy differs from that in non-oil economies. In Saudi Arabia, the receipt of oil revenues adds to government deposits with no immediate impact on domestic liquidity. When the government injects these revenues into the domestic income stream through its domestic expenditure, the inflow of foreign exchange is translated into domestic liquidity. Similarly, external government transactions have no impact on domestic liquidity. It is the private sector's transactions with the rest of the world that affect domestic liquidity. Given a relatively limited home production base and an open economy, the private sector's payments for imports and other external transactions far exceed its receipts from abroad. Private sector imports are highly influenced by government spending, which remains the driving force in the economy. Hence, the government's net domestic expenditure and the private sector's balance of payments deficit control domestic liquidity and provide the basis for constructing causative factors for changes in broad money M3.

The following table for monetary developments in 2005 and 2006 is quite revealing due to monetary policy transition during this period. There was a marked acceleration in M3 growth to $19.3 \%$ in 2006 from $11.6 \%$ in 2005. SAMA's prudential measures slowed down the expansion in bank claims on the private sector (SAR 40.1 billion in 2006 vs SAR 122 billion in 2005). At the same time, the deficit in the private sector's balance of payments continued to grow, owing to the sustained increase in imports (SAR 289.4 billion in 2006 vs SAR 238.3 billion in 2005). These two factors had the effect of slowing M3 growth, but they were substantially offset by the government's increased net domestic expenditure, which amounted to SAR 270.2 billion in 2006 compared with SAR 159 billion in 2005. Miscellaneous factors also exerted a larger expansionary influence on broad money in 2006 as compared to 2005. In short, the government's net domestic expenditure is the major driving factor behind $\mathrm{M} 3$ growth.

\section{Causative factors for changes in broad money (M3)}

Billions of riyals

\begin{tabular}{l|r|r}
\hline & $\mathbf{2 0 0 5}$ & \multicolumn{1}{c}{$\mathbf{2 0 0 6}$} \\
\hline Change in M3 (19.3\% in 2006 vs 11.6\% in 2005) & 57.6 & 106.9 \\
Causative factors & & \\
Net domestic expenditure of the government* & 159.0 & 270.2 \\
Change in bank claims on the private sector & 122.0 & 40.1 \\
Change in bank claims on non-financial public sector enterprises & 2.5 & 3.3 \\
Private sector balance of payments deficit & -238.3 & -289.4 \\
Other items (net) & 12.4 & 82.7 \\
Total & $\mathbf{5 7 . 6}$ & $\mathbf{1 0 6 . 9}$ \\
\hline
\end{tabular}

* Domestic expenditure less domestic revenue of the government.

Source: SAMA 43rd Annual Report.

\section{(v) Interaction of fiscal and monetary policy}

Fiscal policy is dominant in Saudi Arabia and affects monetary policy through direct and indirect channels. 
An expansionary fiscal policy would warrant a restrictive monetary policy in normal times to curb inflationary pressures and vice versa (direct channel).

A more recent analysis regarding the latest developments in advanced economies is that expectations of continuing large budget deficits may trigger a lack of confidence in economic prospects, warranting an expansionary monetary policy to support the financial system (indirect channel).

A third area where fiscal and monetary policies come together is the development of financial markets. On the fiscal side, liquid markets that facilitate deficit funding are crucial for economic development and growth and they also enable the central bank to conduct marketbased operations.

Before the crisis, a standard measure during times of buoyant economic growth was to rebalance the macroeconomic policy mix by tightening monetary policy. Following the global crisis in 2008, both fiscal and monetary policies in Saudi Arabia were set in the same expansionary direction to support demand and ensure continued growth and prosperity. This is an example of how the government has been able to pursue a countercyclical policy against a comfortable cushion, built in good times, in the form of state reserves from cumulative budget surpluses. SAMA's accommodative monetary policy was not adopted primarily to support the banking system, which has shown its resiliency during the crisis. In fact, the capital adequacy ratio of Saudi banks has averaged $16.5 \%$ in the last three years. Inflation has been contained and credit conditions have remained favourable, allowing SAMA to keep monetary conditions easy.

\section{(vi) Development of the financial system}

The Saudi financial system has developed and grown significantly over the past decade. In 2003, a Capital Market Authority was established under the CMA Law to regulate and supervise the securities sector. Since 2003, the CMA has licensed many investment companies, asset management firms, brokers and financial advisors. The emergence of these firms has contributed to the expansion in market activities.

Regulatory coverage of the financial sector was further broadened to include insurance through the enactment of the Cooperative Insurance Companies Control Law of 2003, which entrusted SAMA with the responsibility of supervising Saudi Arabia's insurance sector. At the time of the law's enactment, there was only one licensed company, operating in the country, namely the National Cooperative Company for Insurance ( $\mathrm{NCCl}$ ). Other participants in the insurance sector were branches and agencies of foreign companies that were registered with the Ministry of Commerce. The Insurance Law prescribes that companies wishing to do insurance business in the Kingdom must obtain a license from the authorities. At the end of 2010, some 34 licensed insurance companies were operating in the Saudi insurance market.

The banking system has also expanded phenomenally. The number of banks operating in the Kingdom more than doubled from 11 in December 2000 to 23 by September 2011. Of these banks, 11 are branches of foreign banks and four represent Saudi-foreign joint ventures.

Under the supervision and guidance of the Saudi Arabian Monetary Agency (SAMA), the central bank, the Saudi banking system has become a sound, stable and dynamic banking system. The banks offer a wide range of products and services that can be increasingly accessed through ATMs, internet and phone banking. Over the decades, the Saudi banking system has adopted best international practices in corporate governance, risk management, risk disclosure and transparency. Saudi banks were among the leaders in fully implementing the Basel I framework in 1992 and the Basel II framework in 2008. The banking system is now preparing for the implementation of Basel III on the timelines proposed by the Basel Committee. Over the years, the Saudi banking system has been characterised by strong capital adequacy, ample liquidity and high levels of loan loss coverage. In fact, SAMA has 
encouraged banks to raise capital and provisioning levels on a countercyclical basis. Given a prudent and conservative supervisory stance, there has been no incidence of a bank failure in Saudi Arabia and Saudi banks have shown resilience in the face of recent large regional and global shocks.

In recent years, Saudi banks have remained profitable with the average banking system ROA and ROE at end-December 2010 improving to $1.9 \%$ and $13.2 \%$ respectively. Furthermore, the banks are highly liquid (with a liquid assets-to-deposits ratio of 36\%) and well provisioned against loan losses. In short, Saudi banks are poised to strengthen their performance in coming years as their risk management practices are set to improve further as a result of the shift to Basel III.

For its part, SAMA stands ready to ensure that the banking system is endowed with adequate liquidity to meet the genuine credit needs of the economy. When required, it provides liquidity to banks through its repo facility, foreign exchange swaps and placement of deposits on behalf of autonomous government institutions.

Since the establishment of the Capital Market Authority in 2003, there has been a significant expansion in capital market activity. By the end of December 2010, the number of listed companies had almost doubled to 148 and market capitalisation had reached about SAR 1.3 trillion. By the end of 2010, the number of transactions had reached 19.5 million worth a total of SAR 759 billion. In the asset management sector, the number of investment funds had reached 243 with total assets under management of SAR 94 billion. There is also a nascent sukuk and bond market where total issuance since the market's start-up stands at SAR 43 billion (as at December 2010).

Also of some importance in the Saudi financial system are the five specialised credit institutions that have played an important role in providing long-term credit to vital sectors such as industry, agriculture and real estate. These institutions are funded from loan repayments and the central government's budget. Total disbursements by these institutions since their inception to end-December 2010 amounted to about \$106 billion.

There are also many other non-bank financial institutions, including leasing companies, insurance companies and licensed money changers. These account for only a small share of total financial system assets but their transaction volumes and quality are on the rise.

\section{Performance indicators of the banking sector}

End of period

\begin{tabular}{l|r|r|r}
\hline & $\mathbf{2 0 0 0}$ & $\mathbf{2 0 0 5}$ & $\mathbf{2 0 1 0}$ \\
\hline Number of licensed banks & 11 & 15 & 23 \\
Total assets (percent of GDP) & 65.0 & 64.7 & 85.0 \\
Total private sector loans (percentage of private sector GDP) & 61 & 121 & 154 \\
Risk-weighted capital/assets ratio & 21.0 & 17.8 & 17.1 \\
Liquid assets/customer deposits & 56.0 & 34.0 & 35.7 \\
Loans-to-deposits ratio & 50.1 & 67.5 & 74.0 \\
Leverage ratio & 11.2 & 12.7 & 14.4 \\
\hline
\end{tabular}




\section{Conclusion}

The challenges confronting Saudi Arabia's fiscal policymakers arise from the finite, volatile and uncertain nature of the oil revenues on which the state budget depends. Oil revenues are also influenced by Saudi Arabia's systemic role as a leading producer in stabilising the oil market. This of course means that, on an intergenerational basis, Saudi Arabia is swapping oil revenues for monetary reserves in order to develop its economic base and encourage the private sector to assume a greater role in the country's economic diversification efforts. Given the dominance of fiscal policy in Saudi Arabia and its impact on economic growth, monetary policy aims primarily at exchange rate stability with a view to providing a monetary environment that is conducive to financial stability and sustainable growth over time.

The interaction of fiscal and monetary policy has changed in the current global economic and financial climate. Greater cooperation between fiscal and monetary authorities has become indispensable in meeting macroeconomic objectives. It is envisaged that policy interaction can return to normal modes of operation as the global economic recovery takes hold. 